\title{
Collection of VKM Paleofungi
}

\author{
Galina Kochkina, Nataliya Ivanushkina and Svetlana Ozerskaya *
}

All-Russian Collection of Microorganisms (VKM), G.K. Skryabin Institute of Biochemistry and Physiology of Microorganisms Russian Academy of Sciences (IBPM RAS), Pushchino Scientific Center for Biological Research of the Russian Academy of Sciences (PSCBR RAS), pr. Nauki 5, 142290 Pushchino, Moscow Region, Russia; gak@dol.ru (G.K.); ivanushkina58@mail.ru (N.I.)

* Correspondence: smovkm@gmail.com; Tel.: +7-916-511-97-12

check for

updates

Citation: Kochkina, G.; Ivanushkina, N.; Ozerskaya, S. Collection of VKM Paleofungi. Diversity 2021, 13, 402. https://doi.org/10.3390/d13090402

Academic Editors: Ipek Kurtboke, Angelina Lo Giudice and Carmen Rizzo

Received: 2 August 2021

Accepted: 24 August 2021

Published: 26 August 2021

Publisher's Note: MDPI stays neutral with regard to jurisdictional claims in published maps and institutional affiliations.

Copyright: (c) 2021 by the authors. Licensee MDPI, Basel, Switzerland. This article is an open access article distributed under the terms and conditions of the Creative Commons Attribution (CC BY) license (https:// creativecommons.org/licenses/by/ $4.0 /)$.

\begin{abstract}
A unique collection of paleofungi from permafrost sediments, cryopegs, paleoseeds, and frozen volcanic ash from the Arctic and Antarctic, collected at different depths, was created in All-Russian Collection of Microorganisms (VKM). Some samples are as old as 3 million years. The collection includes psychrotolerant fungi, which have wide adaptive potential and are able to thrive in low-temperature habitats, and fungi that remain viable due to the presence of natural cryoprotectors that ensure the survival of fungal cells during low-temperature preservation in permafrost sediments. The collection contains 780 strains from 79 genera and more than 160 species and is maintained in accordance with international standards of microbial viability preservation and information support.
\end{abstract}

Keywords: mycelial fungi; permafrost; ancient horizons; preservation of viability; collection

\section{Introduction}

When we talk about paleomicology, by analogy with paleobotany, which studies fossil plants, we are referring to an aspect of paleontology that involves a comprehensive study of the fungi of the geological past. Usually, these are findings of fossil remains of higher fungi in ancient sediments. In this paper, we refer to paleofungi as organisms that remain viable in permafrost, which make up a unique natural collection of biomaterial containing samples "deposited" at different times, from thousands to millions of years ago.

The presence of viable prokaryotes in the Earth's cryosphere was discovered at the beginning of the 20th century and was presented in studies by Omelyansky (1911) and Isachenko (1912) [1]. Studies from the second half of the 20th century, conducted in compliance with aseptic principles, showed that eukaryotes remain viable in permafrost soils for long periods of time. As a result, the isolation and identification of extremotolerant fungi living at low temperatures became possible [2,3]. However, mostly the surface horizons have been studied.

Leading mycological collections (CBS, ATCC, and possibly some others) keep strains of mycelial fungi isolated from low-temperature, mainly surficial Antarctic habitats. There are also specialized collections of such fungi. Thus, the Culture Collection of Fungi from Extreme Environments (CCFEE) was created at the Italian National Antarctic Museum (MNA, Section of Genoa); it preserves the biodiversity of Antarctic fungi and contains approximately 500 strains [4].

With the development of comprehensive international programs and the inclusion of mycological topics in programs of international permafrost research, the study of not only the surface, but also the deeper ancient horizons of Arctic and Antarctic permafrost became possible.

The study of subsurface and deeper horizons was also made possible by the development of a dry drilling technique especially for microbiological analysis that allows aseptic sampling from the depths $[5,6]$. This made it possible to prove the presence of fungi in permafrost deposits with, ages covering the entire Pleistocene and part of the Late Pliocene 
period. From a geoecological standpoint, these studies allow access to the "natural storehouse" of biological diversity of past eras before the strong anthropogenic impact on nature started.

There are two main aspects in the research of permafrost fungi:

1. When thawing rocks, paleomicroorganisms, and particularly fungi, can be involved in modern biogeochemical processes, affecting the cycles of elements and providing an additional flow of greenhouse gases into the atmosphere. In this regard, it is very important to assess the number and taxonomic diversity of microorganisms that have remained viable in permafrost during geological time.

2. The problem of low-temperature conservation of microorganisms in nature is very important for basic science due to the need to establish mechanisms for keeping organisms viable for a long time.

\section{Isolation of Fungi}

In investigating the quantitative and qualitative composition of mycelial fungi in the Arctic and Antarctic permafrost, there were isolated strains that subsequently made up a collection of pure cultures from extreme habitats as part of the All-Russian collection of microorganisms (VKM) and then became the objects of study by microbiologists (more than 1100 strains).

In the course of this work, more than 200 samples were taken from the subsurface and deeper layers of Arctic and Antarctic permafrost of different geological epochs, the geological ages of which were established. The strains isolated from these samples constitute the collection of paleofungi.

The sampling was carried in compliance with aseptic principles [7] when drilling special deep boreholes in various regions of the world: the Mackenzie River Delta (Canada), the Kolyma Lowland and Kamchatka (Russia), and the Myers and Taylor Dry Valleys in Antarctica, where the lowest rock temperatures on Earth are recorded. The isolation of fungi was carried out by inoculation on Czapek's medium (Cz) and malt extract agar (MEA), using different temperatures for thawing samples $\left(20,35\right.$, and $\left.52{ }^{\circ} \mathrm{C}\right)$ and cultivation $(4$ and $25^{\circ} \mathrm{C}$ ), and phenotypic and/or genotypic techniques were used for identification [8,9]. To control the sterility of air in the microbiological box, open Petri dishes with agar medium were exposed to the air for $10 \mathrm{~min}$ and then were incubated at 4 and $25^{\circ} \mathrm{C}$ [8].

The depth of sampling exceeded $45 \mathrm{~m}$, and the age of the studied sediments was more than 3 million years. The samples were assigned to the Holocene, Pleistocene, and late Pliocene periods in Earth's history. The list of dated samples is given in Table 1.

Table 1. Structure of collection of paleofungi by age of the studied samples.

\begin{tabular}{cccc}
\hline Epoch & $\begin{array}{c}\text { Age of Studied } \\
\text { Samples } \\
\text { (Thousand Years) }\end{array}$ & Number of Samples & $\begin{array}{c}\text { Number of Isolated } \\
\text { Strains }\end{array}$ \\
\hline Holocene & $0-10$ & 62 & 211 \\
Late Pleistocene & $10-100$ & 59 & 200 \\
Middle Pleistocene & $100-600$ & 32 & 199 \\
Early Pleistocene & $600-1800$ & 14 & 24 \\
Pliocene & $1800-3000$ & 34 & 146 \\
\hline
\end{tabular}

During this study, it was revealed that the negative temperatures of frozen strata, at which the rates of biochemical reactions and biological processes become extremely low, do not limit the preservation of viability. On the contrary, it appears that the stable state of the basic physicochemical parameters is most likely a factor promoting the development of adaptive mechanisms in biological systems that prolong their viability during geological time. We discovered a microfocal distribution of fungi in permafrost samples of different ages [10]. Only $7 \%$ of the samples showed the absence of viable filamentous fungi. The fungal biodiversity was also not connected to younger sediments. 


\section{Description of Collection}

\subsection{Types of Samples}

The collection is made up of strains isolated from different types of samples. In the Arctic region, there are permafrost sediments of diverse genesis with ages from 5-10 thousand up to 2-3 million years and from various depths (Kolyma lowland, Russia); cryopegs (Kolyma lowland, Russia); permafrost sediments of diverse genesis from various depths with ages from 10 thousand to 2.5 million years (McKenzie River delta, Canada); frozen volcano ash (deep layers) (Kamchatka, Russia); fossil seeds and embedded frozen material and ancient ground squirrels burrowing in permafrost, 32 thousand years (Kolyma lowland, Russia); and the mummy of the Bilibino horse, 31-58 thousand years (Chukotka, Russia). In the Antarctic region there are permafrost sediments of diverse genesis with different ages and depths in dry valleys (Meyer, Taylor, and Beacon Valleys), and in the eternal ice and glaciers of Central Antarctica.

Due to the variety of studied substrates, it should be noted that $74 \%$ of the strains stored in the collection are isolated from permafrost sediments of various nature, $10 \%$ from the salt water of cryopegs and $9 \%$ from frozen volcanic ash. Approximately $2-2.5 \%$ of the strains were isolated from the following substrates: the surface of fossil seeds preserved in gopher burrows and embedded in frozen material, the surface of a fossilized horse found in permafrost, and glaciers.

\subsection{Taxonomic Diversity}

The collection of paleofungi includes 780 strains belonging to 79 genera and more than 160 species (Table S1). Some strains were not identified by cultural methods, as they represent sterile mycelia, which are often isolated from samples taken from Arctic and Antarctic habitats. Determining their taxonomic composition, quantity, distribution by borehole profile, and potential ability to decompose organic matter is now quite relevant. According to our estimates, based on molecular biological identification of many strains from the collection of paleofungi, basidiomycetous fungi make up about half of all sterile mycelia from permafrost.

The majority of fungi in the collection comprises ascomycetous anamorphs. Basidiomycetous fungi comprise up to $4 \%$ of all stored strains, and 1\% are zygomycetous fungi.

Among the classes of ascomycetous fungi, Eurotiomycetes has the largest number of strains due to the high representation of the genus Penicillium, with 241 strains in the collection (Figure 1). Next in number are the classes Dothideomycetes and Leotiomycetes, which have a special position in the study of the Arctic and Antarctic. Among the representatives of these classes, fungi show the greatest diversity, with a high frequency of occurrence in low-temperature ecotopes [9]. There are markedly fewer members of the class Sordariomycetes, and the classes Pezizomycetes and Saccharomycetes are represented by one or two genera.

\subsection{Adaptive Properties}

Long-term research of low-temperature habitats of mycelial fungi has allowed us to establish that the mycobiota of permafrost can be divided into two groups: psychrotolerant fungi, which have wide adaptive potential and are capable of developing in this ecotope, and fungi that remain viable due to the presence of natural cryoprotectants that ensure the survival of fungal cells in the process of low-temperature conservation in permafrost sediments. As these groups are of great interest to researchers, both scientifically and practically, they were deposited in our collection. 


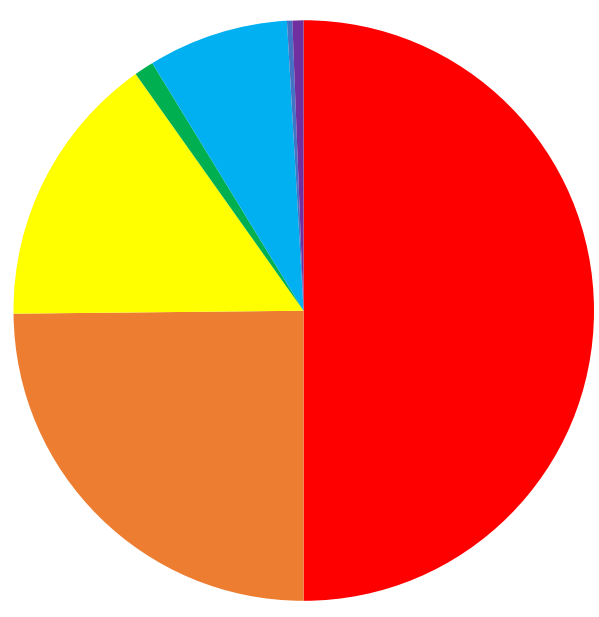

Eurotiomycetes

Dothideomycetes

Leotiomycetes

Saccharomycetes

Sordariomycetes

Pezizomycetes

Incertae sedis

Figure 1. Composition of ascomycetous fungi in collection of paleofungi.

Different substances and even biological objects can possess protective properties in relation to fungi. For example, in experiments on paleoseeds of higher plants found in gopher burrows in permafrost over 30 thousand years old, it was shown that seeds are a special habitat for microorganisms contributing to their preservation in the permafrost. Representatives of fungal species inherent to these plants have been preserved on the seeds, which are natural protectors, and their number was also very high. It was established that the ancient seeds of narrow-leafed campion (Silene stenophylla) were dominated by fungi of the genus Phoma; the frequency of occurrence of isolated Phoma crystallifera reached $70 \%$ in the studied seed samples. At the same time, the number and species composition of fungi from the frozen mass in which the seeds were embedded were very different from those of the fungal community of the seeds themselves, which indirectly confirms the protective effect of this natural substrate [11].

The fact that representatives of most strains of sterile mycelium identified by molecular biological methods belong to plant-associated species serves as further confirmation of the hypothesis regarding the possibility of preserving fungi, including higher taxa, in permafrost in the presence of natural cryoprotectants. Wood-destroying basidiomycetous fungi, which mainly cause white rot of wood of various species, including Antrodia malicola, Bjerkandera adusta, Schizophyllum commune, and others, are present among the identified species. Phytopathogenic fungi have been identified, such as the basidiomycetous Thanatephorus cucumeris, which causes rot in vegetable crops [12]; ascomycetous Phaeosphaeria, which is a pathogen of bread cereal leaves [13]; ascomycetous anamorphic species of the genus Phoma, which cause phomosis wilt of various crops [14]; and representatives of the genus Alternaria, pathogenic agents of plant disease [15].

These fungi, as well as many others that have retained their viability in the presence of natural cryoprotectants, are kept in the collection of paleofungi.

Another group of organisms with high adaptive properties includes fungi of the genera Penicillium, Cladosporium, and Pseudogymnoascus (anamorphic state (am): Geomyces), which are the most widely distributed in permafrost.

\subsubsection{Penicillium}

The genus Penicillium is represented in our collection as the most diverse: 241 strains belonging to 43 species, including P. chrysogenum (41 strains), P. aurantiogriseum (24 strains), P. minioluteum (22 strains), P. variabile (17 strains), and P. palitans (8 strains). Possible adaptation of these fungi to low-temperature conditions is indirectly confirmed by the data obtained in our study [7]. This reflects a clear tendency of cultures of these genera isolated from permafrost sediments to grow preferentially at low temperatures. 
Eighty-five strains of the genus Penicillium preserved in the collection of paleofungi isolated from sediments of the Arctic and Antarctica with known geological age were tested for their secondary metabolite production capability. Methods for investigating secondary metabolites have been described in detail previously [16]. Since secondary metabolites provide a competitive advantage for fungus producers for survival in extreme ecotopes, such a search among paleo- and extremotolerant fungi is valid. The presence of producers of potentially useful substances among the paleofungi is confirmed in this study.

Among the studied micromycetes, 47 secondary metabolites were found with an already known chemical structure and two new metabolites from the group of quinoline alkaloids, quinocitrinins A and B. They were discovered for the first time in P. citrinum strain VKM F-4043D (FW-800) isolated from permafrost Pliocene deposits occurring at a depth of $11.5 \mathrm{~m}$ in the Kolyma lowland [17]. Quinocitrinins exhibit a wide range of antimicrobial activity and are cytotoxic to tumor cells. Later, these substances were found in P. waksmanii strain VKM F-4431 (FW-2875) isolated in an estuary of the Bolshaya Chukochya River (Kolyma lowland) from the horizon lying at a depth of $31.3 \mathrm{~m}$ and dated at 100-200 thousand years. Both strains also produce a clavin series alkaloid, epoxyagroclavin I, which is of great practical interest for its diverse biological activities [18]. This compound is known to possess neurotropic activity and have a moderate hypotensive effect.

Other antibiotics have also been found. The study of $P$. chrysogenum showed the presence of producers of two antibiotics, questiomycin A and xanthocillin $\mathrm{X}$, among the strains isolated from late Pleistocene deposits of the Kolyma lowland sampled at a depth of $15.6 \mathrm{~m}$, and from the Holocene frozen volcanic ash of Kamchatka at a depth of $9.6 \mathrm{~m}$. Xanthocillin $X$ has the widest antibacterial spectrum of action, and bacteria remain sensitive to it for a long time [16]. Questiomycin A inhibits pulmonary metastasis caused by melanoma cells in mice [19].

In studying isolates from cryopegs, P. thymicola strain VKM F-4453 was discovered, isolated from cryopeg water at a depth of 17.00-21.00 m (horizon age 100-120 thousand years). This strain also synthesized two substances with high antitumor activity, fumiquinazolines $F$ and $G[20]$.

In general, most detected compounds (49\%) belong to diketopiperazine and clavin alkaloids. Quinoline alkaloids and polyketides account for $12.2 \%$ each, and benzodiazepine alkaloids, quinazoline alkaloids, and amino acid derivatives are present in equal shares of $8.2 \%$. One secondary metabolite (PR toxin) belongs to the terpene group (2\%) (Figure 2).

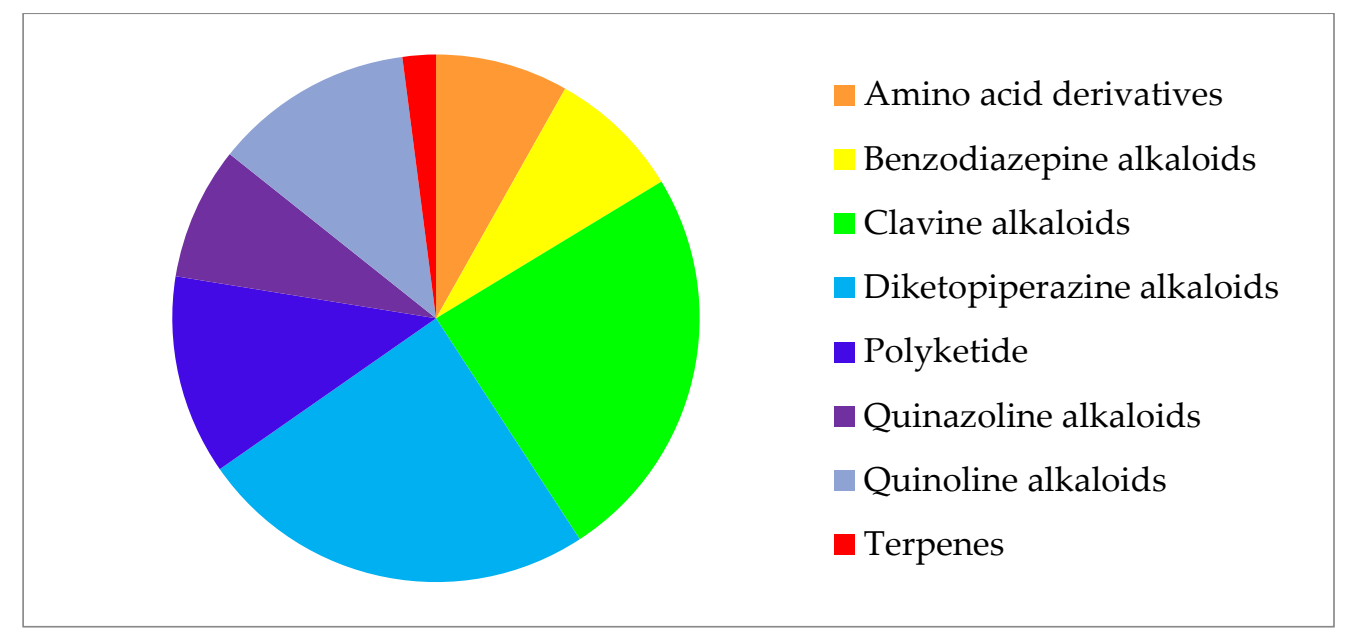

Figure 2. Secondary metabolites of Penicillium strains from collection of paleofungi.

The data above confirm that the study of fungi from the circumpolar regions is very promising for biotechnology and medicine. 


\subsubsection{Cladosporium}

Besides representatives of the genus Penicillium, the group of fungi capable of metabolism in the Arctic and Antarctica includes those from the genus Cladosporium. Micromycetes of this genus are found everywhere; their adaptive potential is very high They are isolated from plant residues, phyllioplanes, and soils of different types at different latitudes, including the Arctic and Antarctic regions.

These fungi occur in marine habitats, they are resistant to high salt content (osmotolerant), and they withstand fairly high doses of radiation. In our studies, they were found in the salty lenses of cryopegs of the Kolyma lowland (temperature -9 to $-11^{\circ} \mathrm{C}$, salinity 170-300 g/L, age 100-120 thousand years) [21]. They are also often observed in ancient permafrost deposits, in frozen volcanic ash.

Our analysis of fungal species found in studies of Antarctic samples by different researchers confirmed that the species $C$. cladosporioides and $C$. herbarum are among the most common in Antarctica [10,22]. However, while the range of growth temperatures for fungi that only persist in permafrost does not differ from those of strains isolated in temperate climates, for fungi of the genus Cladosporium this is not the case. High-latitude strains have higher growth rates at lower temperatures and a lower growth rate at a temperature of $26^{\circ} \mathrm{C}$ than isolates from samples of central Russia [7]. The collection of paleofungi of VKM stores 106 strains of the genus Cladosporium, isolated from deposits of diverse ages.

\subsubsection{Pseudogymnoascus}

Extremotolerant fungi of the genus Pseudogymnoascus (am Geomyces) occur most often in permafrost soils. They are represented in the collection of paleofungi by 87 strains and are included in the group of fungi that are capable of not only survival, but also active life under conditions of high salinity and low temperature. These micromycetous fungi, according to our data, are best adapted to existence in low temperatures. They have frequent occurrence and high abundance in permafrost deposits. It should be noted that it has been cultures of the species P. pannorum that have been isolated from the Arctic cryopegs most often. Their occurrence in these habitats reached $75 \%$, and the abundance in some variants reached $100 \%$ [23]. This fungus also dominated in soil samples collected near cryopegs, making up about $90 \%$ of all isolated strains.

The assumption that fungi of the genus Pseudogymnoascus from cryopegs are adapted to growth in microaerophilic conditions has been confirmed, since high salt concentrations cause not only osmotic, but also oxidative shock, and cell functioning in microaerophilic conditions reduces the effects. It was shown that the growth of the Arctic cryopeg strain at $6{ }^{\circ} \mathrm{C}$ under various redox conditions was accompanied by the accumulation of acetate and lactate in the culture liquid as fermentation products. Moreover, the presence of sodium chloride in the medium only increased the activity [24]. These fungi are capable of growth at very low positive and even at slightly negative temperatures $\left(-2{ }^{\circ} \mathrm{C}\right)$, although they are neither true halophiles nor psychrophiles. Fungi of this genus contribute essentially to the carbon cycle and ecosystem functioning at extremely low temperatures, manifesting as wood-destroying fungi [25]. The prospect of searching for producers of useful compounds among psychrotolerant strains of P. pannorum has been reported. For example, a strain isolated in the Arctic tundra in Western Svalbard is capable of oxidative biotransformation of $\alpha$-pinene, with formation of an expensive aromatic substance, verbenol, used in the cosmetic and perfume industries. The process occurs most actively at low temperatures, and the effect of various abiotic stressors on the strain can increase its productivity [26].

The presence of Pseudogymnoascus strains in the VKM allows to study not only the adaptive potential of these micromycetes, but also their taxonomy. The full genome was studied in 14 strains of P. pannorum from a collection of extremotolerant fungi isolated from both present-day samples and permafrost aged up to 3 million years (Collection of Paleofungi). The comparison of currently existing and ancient strains allows us to assert that this species is an ancient (at least 50 million years old) clonal cloud with several distinct 
clades [27]. Further taxonomic study of this genus will allow us to describe new species preserved in permafrost.

\subsection{Preservation Methods}

Paleofungi are in demand by researchers and are actively provided for scientific research [27-30]. Conducting scientific research is directly related to ensuring the preservation of strains from unique habitats in specialized collections. Strains are stored using different methods, which provide long-term preservation of their viability: low temperature, lyophilization and storage under Vaseline oil.

\subsection{Data Base}

Information in support of the collection of paleofungi is provided in accordance with international standards for maintaining collections of microorganisms. We developed a database on the strains of paleofungi intended for storage, search, and information analysis.

The database contains information about the following:

- The nomenclature of fungal species;

- Sources of fungal isolation;

- The geographic locations of the samples where the strains were isolated;

- Methods of storage and conditions of cultivating the strains;

- The properties of the strains; and

- $\quad$ Published material indicating strain numbers.

Information on paleofungi strains will be updated periodically as molecular biological studies on the taxonomy of strains belonging to species not yet determined are carried out.

Supplementary Materials: The following are available online at https:/ / www.mdpi.com/article/10 .3390/d13090402/s1, Table S1: Taxonomic diversity of Collection of Paleofungi.

Author Contributions: Conceptualization, S.O., G.K. and N.I.; methodology, S.O., G.K. and N.I.; validation, S.O., G.K. and N.I.; investigation, S.O., G.K. and N.I.; writing-original draft preparation, G.K.; writing-review and editing, S.O. and N.I. All authors have read and agreed to the published version of the manuscript.

Funding: This research received no external funding.

Data Availability Statement: Data is contained within the article.

Conflicts of Interest: The authors declare no conflict of interest.

\section{References}

1. Gilichinsky, D.A. Permafrost Model of Extraterrestrial Habitat. In Astrobiology the Quest for the Conditions of Life; Horneck, G., Baumstark-Khan, C., Eds.; Springer: Berlin/Heidelberg, Germany, 2002; pp. 125-142. [CrossRef]

2. Tubaki, K.; Asano, I. Additional Species of Fungi Isolated from the Antarctic Materials. JARE Sci. Rep. 1965, $27,1-12$.

3. Broady, P.; Given, D.; Greenfield, L.; Thompson, K. The biota and environment of fumaroles on Mt Melbourne, northern Victoria Land. Polar Biol. 1987, 7, 97-113. [CrossRef]

4. Schiaparelli, S.; Selbmann, L.; Onofri, S.; Zucconi, L.; Isola, D.; Rottigni, M.; Ghiglione, C.; Piazza, P.; Alvaro, M.C. Distributional records of Antarctic fungi based on strains preserved in the Culture Collection of Fungi from Extreme Environments (CCFEE) Mycological Section associated with the Italian National Antarctic Museum (MNA). MycoKeys 2015, 10, 57-71. [CrossRef]

5. Gilichinskiy, D.A.; Khlebnikova, G.M.; Zvyagintsev, D.G.; Fedorov-Davydov, D.G.; Kudryavtseva, N.N. Microbiology of Sedimentary Materials in the Permafrost Zone. Int. Geol. Rev. 1989, 31, 847-858. [CrossRef]

6. Gilichinsky, D.; Wilson, G.; Friedmann, E.; McKay, C.; Sletten, R.; Rivkina, E.; Vishnivetskaya, T.A.; Erokhina, L.; Ivanushkina, N.; Kochkina, G.; et al. Microbial Populations in Antarctic Permafrost: Biodiversity, State, Age, and Implication for Astrobiology. Astrobiology 2007, 7, 275-311. [CrossRef]

7. Ivanushkina, N.E.; Kochkina, G.A.; Ozerskaya, S.M. Fungi in Ancient Permafrost Sediments of the Arctic and Antarctic Regions. In Life in Ancient Ice; Castello, J., Rogers, S., Eds.; Princeton University Press: Princeton, NJ, USA, 2005; Chapter 9, pp. 127-139. [CrossRef]

8. Kochkina, G.A.; Ivanushkina, N.; Karasev, S.G.; Gavrish, E.Y.; Gurina, L.V.; Evtushenko, L.I.; Spirina, E.; Vorob’Eva, E.A.; Gilichinskii, D.A.; Ozerskaya, S. Survival of Micromycetes and Actinobacteria under Conditions of Long-Term Natural Cryopreservation. Microbiology 2001, 70, 356-364. [CrossRef] 
9. Kochkina, G.A.; Ivanushkina, N.; Lupachev, A.V.; Starodumova, I.P.; Vasilenko, O.V.; Ozerskaya, S.M. Diversity of mycelial fungi in natural and human-affected Antarctic soils. Polar Biol. 2018, 42, 47-64. [CrossRef]

10. Ozerskaya, S.; Kochkina, G.; Ivanushkina, N.; Gilichinsky, D. Fungi in Permafrost. In Permafrost Soils; Margesin, R., Ed.; Springer: Berlin/Heidelberg, Germany, 2009; Chapter 7, pp. 85-95.

11. Stakhov, V.L.; Gubin, S.V.; Maksimovich, S.V.; Rebrikov, D.; Savilova, A.M.; Kochkina, G.A.; Ozerskaya, S.; Ivanushkina, N.; Vorobyova, E.A. Microbial communities of ancient seeds derived from permanently frozen Pleistocene deposits. Microbiology 2008, 77, 348-355. [CrossRef]

12. Jayasinghe, C.; Wijayaratne, S.; Fernando, T. Characterization of cell wall degrading enzymes of Thanatephorus cucumeris. Mycopathologia 2004, 157, 73-79. [CrossRef] [PubMed]

13. Bennett, R.; Milgroom, M.G.; Bergstrom, G. Population Structure of Seedborne Phaeosphaeria nodorum on New York Wheat. Phytopathology 2005, 95, 300-305. [CrossRef]

14. Deb, D.; Khan, A.; Dey, N. Phoma diseases: Epidemiology and control. Plant. Pathol. 2020, 69, 1203-1217. [CrossRef]

15. Simmons, G.S. Alternaria: An Identification Manual; CBS Biodiversity Series 6; CBS Fungal Biodiversity Centre: Utrecht, The Netherlands, 2007; 775p.

16. Kozlovskii, A.G.; Antipova, T.; Zhelifonova, V.P.; Baskunov, B.P.; Kochkina, G.A.; Ozerskaya, S. Exometabolites of the fungal isolates (Genus Penicillium, Section Chrysogena) from low-temperature ecotopes. Microbiology 2016, 85, 157-164. [CrossRef]

17. Kozlovsky, A.G.; Zhelifonova, V.P.; Antipova, T.V.; Adanin, V.M.; Ozerskaya, S.M.; Kochkina, G.A.; Schlegel, B.; Dahse, H.M.; Gollmick, F.A.; Gräfe, U. Quinocitrinines A and B, new quinoline alkaloids from Penicillium citrinum Thom 1910, A permafrost fungus. J. Antibiot. 2003, 56, 488-491. [CrossRef]

18. Kozlovsky, A.G.; Zhelifonova, V.P.; Antipova, T.; Zelenkova, N.F. Physiological and biochemical characteristics of the genus Penicillium fungi as producers of ergot alkaloids and quinocitrinins. Appl. Biochem. Microbiol. 2011, 47, 426-430. [CrossRef]

19. Hongo, T.; Miyano-Kurosaki, N.; Kurosaki, K.; Hata, A.; Harigae, S.; Tomoda, A. 2-aminophenoxazine-3-one prevents pulmonary metastasis of mouse B16 melanoma cells in mice. J. Pharmacol. Sci. 2010, 114, 63-68. [CrossRef] [PubMed]

20. Kozlovskii, A.G.; Zhelifonova, V.P.; Antipova, T.; Baskunov, B.P.; Kochkina, G.A.; Ozerskaya, S. Secondary metabolite profiles of the Penicillium fungi isolated from the arctic and antarctic permafrost as elements of polyphase taxonomy. Microbiology 2012, 81, 306-311. [CrossRef]

21. Gilichinsky, D.; Rivkina, E.; Bakermans, C.; Shcherbakova, V.; Petrovskaya, L.; Ozerskaya, S.; Ivanushkina, N.; Kochkina, G.; Laurinavichuis, K.; Pecheritsina, S.; et al. Biodiversity of cryopegs in permafrost. FEMS Microbiol. Ecol. 2005, 53, 117-128. [CrossRef] [PubMed]

22. Gesheva, V.; Negoita, T. Psychrotrophic microorganism communities in soils of Haswell Island, Antarctica, and their biosynthetic potential. Polar Biol. 2011, 35, 291-297. [CrossRef]

23. Ozerskaya, S.; Ivanushkina, N.; Kochkina, G.; Fattakhova, R.; Gilichinsky, D. Mycelial fungi in cryopegs. Int. J. Astrobiol. 2004, 3, 327-331. [CrossRef]

24. Shcherbakova, V.A.; Kochkina, G.A.; Ivanushkina, N.; Laurinavichius, K.S.; Ozerskaya, S.; Akimenko, V.K. Growth of the fungus Geomyces pannorum under anaerobiosis. Microbiology 2010, 79, 845-848. [CrossRef]

25. Blanchette, R.A.; Held, B.W.; Arenz, B.E.; Jurgens, J.A.; Baltes, N.J.; Duncan, S.M.; Farrell, R.L. An Antarctic Hot Spot for Fungi at Shackleton's Historic Hut on Cape Royds. Microb. Ecol. 2010, 60, 29-38. [CrossRef] [PubMed]

26. Trytek, M.; Jędrzejewski, K.; Fiedurek, J. Bioconversion of $\alpha$-pinene by a novel cold-adapted fungus Chrysosporium pannorum. J. Ind. Microbiol. Biotechnol. 2014, 42, 181-188. [CrossRef] [PubMed]

27. Leushkin, E.V.; Logacheva, M.D.; Penin, A.; Sutormin, R.A.; Gerasimov, E.S.; Kochkina, G.A.; Ivanushkina, N.; Vasilenko, O.V.; Kondrashov, A.S.; Ozerskaya, S.M. Comparative genome analysis of Pseudogymnoascus spp. reveals primarily clonal evolution with small genome fragments exchanged between lineages. BMC Genom. 2015, 16, 1-15. [CrossRef] [PubMed]

28. Fomicheva, G.M.; Vasilenko, O.V.; Marfenina, O.E. Comparative morphological, ecological, and molecular studies of Aspergillus versicolor (Vuill.) tiraboschi strains isolated from different ecotopes. Microbiology 2006, 75, 186-191. [CrossRef]

29. Crous, P.; Wingfield, M.; Lombard, L.; Roets, F.; Swart, W.; Alvarado, P.; Carnegie, A.; Moreno, G.; Luangsa-Ard, J.; Thangavel, R.; et al. Fungal Planet description sheets: 951-1041. Persoonia Mol. Phylogeny Evol. Fungi 2019, 43, 223-425. [CrossRef]

30. Vinokurova, N.G.; Ivanushkina, N.; Khmel'Nitskaya, I.I.; Arinbasarov, M.U. Synthesis of $\alpha$-cyclopiazonic acid by fungi of the genus Aspergillus. Appl. Biochem. Microbiol. 2007, 43, 435-438. [CrossRef] 